\title{
Succession and livestock grazing in a northeast- ern Oregon riparian ecosystem
}

\author{
DOUGLAS M. GREEN, AND J. BOONE KAUFFMAN
}

\begin{abstract}
Authors are assistant professor, School of Agribusiness and Environmental Resources, Arizona State University, Tempe 85287; and associate professor, Department of Rangeland Resources, Oregon State University; Convallis 97331. At the time of the research the senior author was a research assistant, Department of Rangeland Resources, Oregon State University:
\end{abstract}

\begin{abstract}
Comparisons of vegetation dynamics of riparian plant communities under livestock use and exclusions over a 10 year period were quantified in a Northeastern Oregon riparian zone. We measured species frequency, richness, diversity, evenness, and livestock utilization in 8 plant communities. Livestock grazed the study area from late August until mid September at a rate of 1.3 to 1.8 ha/AUM. Utilization varied from $>70 \%$ in dry meadows to $<3 \%$ in cheatgrass dominated stands. Ungrazed dry and moist meadow communities had significantly lower $(P \leq 0.1)$ species richness and diversity when compared to grazed counterparts. In the most heavily grazed communities, ruderal and competitive ruderal species were favored by grazing disturbance. In exclosures of the same communities, competitive or competitive stress tolerant species were favored. Both height and density of woody riparian species were significantly greater in ungrazed gravel bar communities. Our results indicate that influences of herbivory on species diversity and eveness varies from 1 community to another and basing management recommendation on 1 component ignores the inherent complexity of riparian ecosystems.
\end{abstract}

Key Words: riparian, grazing, community succession, species diversity, disturbance

Riparian areas are important linkages between instream aquatic and terrestrial ecosystems. This is demonstrated by the influence of riparian vegetation on: a) the structure and stability of stream banks (Platts 1979, Swanson et al. 1982, Harmon et al. 1986, Robison and Beschta 1990); b) solar energy inputs through shading (Meehan et al. 1977); c) nutrient and energy dynamics through litterfall, denitrification, and sediment retention (Green and Kauffman 1989). In addition, vegetation associated with intact riparian areas decreases overland sediment inputs into the stream (Brown 1983, Cooper et al. 1987, Heede 1990). Riparian areas also influence nutrient dynamics of stream ecosystems (Triska et al. 1982, Peterjohn and Correll 1984, Hussey et al. 1985, Green and Kauffman 1989).

Livestock grazing in western rangelands have had a dramatic influence on riparian ecosystem structure and function and

Manuscript accepted 24 Ost. 1994. improved management strategies is an important environmental concern today (Bryant 1985, Elmore 1992). Many livestock grazing strategies have been discussed for riparian area rehabilitation or maintenance (Elmore 1992). In a review of 17 grazing strategies Platts (1989) stated that fisheries habitat was negatively affected by increasing livestock use. Results of studies conducted in uplands and riparian ecosystems indicate that, utilization of use is of greater importance than the specific grazing scheme utilized (Van Poolen and Lacy 1979, Skovlin 1984, Clary and Webster 1989).

Few studies have quantified variation in vegetation response over many years in different plant communities within the same riparian system. This is important as the impact of grazing on plant communities and species is expected to differ due to differential resource availability, regrowth opportunities, and pressure exerted by livestock on each species.

The objective of this study was to quantify changes in vegetation species composition and over 10 years of 8 grazed and ungrazed riparian plant communities.

\section{Study Site}

The study site is located in the Wallowa Mountains of northeastern Oregon at an elevation of $1,030 \mathrm{~m}$. The riparian area is approximately 100 ha in size, and extends for approximately 3 $\mathrm{km}$ along Catherine Creek. Average discharge is $3.4 \mathrm{~m}^{3} / \mathrm{sec}$ and peak flows greater than $14.3 \mathrm{~m}^{3} / \mathrm{sec}$ commonly occur from April to early June (USGS 1987). Mean annual precipitation for the study site is $600 \mathrm{~mm}$, the majority of which falls as snow during the winter months. Precipitation in 1980 and 1989 was 5.8 and $1.2 \mathrm{~mm}$ above average, respectively. Precipitation in 1979, 1987. and 1988 was 45,102 , and $57 \mathrm{~mm}$ below average.

Kauffman (1982) subjectively segregated the study area into 256 stands of vegetation representing 60 plant communities in the Catherine Creek riparian area. Plant communities were selected to provide a continuation of the study conducted by Kauffman (1982 and Kauffman et al. 1983) and represent the 8 most widely occurring plant communities in the study area. These communities are: Poa pratensis L.-Phleum pratense L. Carex spp.-mixed dicot (moist meadow communities), Poa pratensis-mixed dicot 
(dry meadow communities), Bromus tectorum L. (cheatgrass communities) located on severely disturbed sites, Pinus ponderosa Dougl. Ex Loud./Poa pratensis (ponderosa pine communities), Populus trichocarpa T. \& E. Ex Hook.-mixed conifer (black cottonwood communities), Alnus incana (L.) Moench./ Poa pratensis (thinleaf alder communities), Crataegus douglasii Lindl./Poa pratensis (Douglas hawthorn communities), and Salix spp.-mixed dicot (gravel bar communities).

\section{Method}

In 1978, five livestock exclosures were constructed that occupy approximately one half of the riparian area within 50 meters of the stream. Since 1978, grazing has begun in late August and continued for 3 to 4 weeks. Stocking rates ranged from 1.3 to 1.8 hal AUM.

We quantified species changes by measuring frequency in thirty $25 \times 25 \mathrm{~cm}$ plots in 6 stands of each community. One half of the replications were in the grazed areas and the other half of the replications were located in the exclosures. Frequency sampling was done from late June to early July when most perennial species were in a phenological stage that would facilitate identification. Following the grazing period, utilization was visually estimated in 15 microplots in each sampled stand.

Values for plant species diversity and evenness were calculated from frequency data using the AIDN program (Overton et al. 1987). We selected Shannon's index $\left(\mathrm{H}^{\prime}\right)$ (Shannon and Weaver 1949 ) to evaluate species diversity as it provides an intermediate weighing of rare species compared to Simpson's index $(\lambda)$ and Hill's first number (N1) (Peet 1974). Pielou's J' was selected to evaluate eveness (Pielou 1975). Eveness expresses how species abundances are distributed among the species. A community with a large number of species would have a lower eveness than a community with the same number of species, but not dominated by any one species. Species richness is defined as the total number of species in the community (Ludwig and Renolds 1988). Minor differences in values of species richness, diversity, and eveness between this paper and earlier reported values (i.e. Kauffman 1982, Kauffman et al. 1983, Kauffman et al. 1988) reflect consolidation of certain species in the 1979 and 1980 data sets.

We measured shrub density, height, and composition in ten 1$\times 1-\mathrm{m}$ plots in each community. Six replicate stands located on gravel bar communities were sampled with one half of the replications located in grazed areas and the other half located in exclosures. Gravel bar communities were the only communities that contained significant numbers of establishing woody riparian species.

Changes in individual species frequency between years and treatments were tested using a $2 \times 4$ factorial design (Steele and Torrie 1980). Factors included treatments (grazed and exclosed) and years $(1979,1980,1987$, and 1989). Data were arcsine transformed where necessary to meet statistical assumptions (Ahrens et al. 1990).

Nonparametric analysis of variance (Kruskal-Wallis procedure) (Zar 1984) was used to detect changes in species richness, species diversity, and evenness between communities within years and treatments. When a significant change occurred in species richness, species diversity, or evenness, a nonparametric Turkey multiple comparison test were used to separate differences (Zar
1984). Significance limits for all tests were set at $P \leq 0.1$ due the highly heterogeneous nature of riparian ecosystems.

Differences between years within treatments and between treatments within years for shrub densities, were tested using Student's test (Steele and Torrie 1980).

\section{Results}

\section{Meadow Communities}

Dry meadow communities were the most highly utilized communities by livestock. Utilization of dry meadow communities ranged from 48 to 70 percent in grazed stands (Fig. 1).

In the exclosures, species richness was significantly higher in 1989 than in 1979 (Table 1). Significant differences within years and between treatments also occurred. For all years studied, species richness was significantly lower in the exclosed areas of dry meadow communities.

During the course of the study, community species diversity increased significantly in cxclosed and grazed areas. For all years, species richness and species diversity were significantly lower in the exclosed areas. In grazed areas evenness increased significantly from 0.75406 to 0.86805 from 1979 to 1989 , indicating increasingly even distribution of species abundances. Between treatments, significant differences occurred for eveness in 1987 and 1989 where the grazed treatment had a higher eveness than the exclosed treatment (Table 1).

Species composition of grazed dry meadows displayed little change over the study period with the abundance of species such as Achillea millefolitum $\mathrm{L}$. and Poa pratensis remaining almost constant at $70.8 \%$ and $100.0 \%$ respectively. Within exclosures Achillea millefolium was significantly less frequent than the grazed treatment in 1979, 1987, and 1989. The alien species, Bromus mollis L. increased dramatically, from $1.7 \%$ to $47.5 \%$, in the grazed treatment from 1979 to 1989 while at the same it displayed a declining trend in the exclosures.

Levels of livestock utilization in moist meadow communities were comparable to dry meadow communities. Significantly higher species richness occurred in the grazed than exclosed treatments of moist meadow communities in 1989 (Table 1). No significant differences for species diversity were detected within treatments between years. Species diversity was significantly higher in grazed moist meadow communities than ungrazed treatments in 1989. Within year treatment comparisons revealed higher eveness in the exclosed treatment $(0.81624)$ than the grazed treatment (0.78921) in 1979; other comparisons were not significant.

Livestock had significant impacts on species composition in moist meadows for example, the frequency of Phleum pratense, an exotic species, decreased significantly in the exclosed treatment from $33 \%$ in 1979 to $3.3 \%$ in 1989 . Poa pratensis declined in the exclosures, but this decline was not significant. Ranunculus acris L. also an exotic species declined significantly in abundance in the exclosures (55.5\% in 1979 to $12.2 \%$ in 1989) while remaining relatively constant in the grazed treatment.

\section{Cheatgrass Communities}

Utilization of Cheatgrass communities by livestock never exceeded $2 \%$ (Fig. 1). This is most likely due to the dry and dormant vegetation of this community when cattle were present. This low rate of utilization in an extremely perturbed ecosystem, 
contributed to few changes occurring over time in this community.

The relative abundance of exotic species in cheatgrass communities was higher than all other communities. Exotic species accounted for $50 \%$ of total species encountered in 1979 and $57 \%$ in 1989 in exclosures. In grazed communities, exotics accounted for $46 \%$ of the species composition in 1979 and $61 \%$ of total species in 1989 (Table 1).

\section{Douglas Hawthorne Communities}

Livestock utilization appeared to be inversely related to the canopy cover of Douglas hawthorne. Utilization was the highest of any tree or shrub dominated community; although it was lower than the dry and moist meadow communities (Fig. 1).

The abundance of exotic species declined from 1979 to 1989 in both treatments (Table 1). Species richness was significantly lower in the exclosed treatments than the grazed treatments in 1980. Species diversity was not significantly different between years within treatments, however species diversity was significantly lower in the exclosed treatments in 1980 compared to the grazed treatment (3.0209 vs 3.3251).

Despite levels of utilization lower than meadow communities, significant changes in species frequency occurred in Douglas hawthorne communities. Achillea millefolitm was significantly more abundant in exclosures than grazed areas, 58.4 vs 17.5 in 1987 and 67.5 vs 22.5 in 1989 . Similar to dry meadow, thin leaf alder and ponderosa pine other communities, the abundance Taraxacum officinale Weber declined significantly from $54.2 \%$ in 1980 to $10.1 \%$ in 1989. Poa pratensis had significantly lower frequencies in 1987 and 1989 when grazed.

\section{Tree-Dominated Communities}

Livestock utilized tree-dominated communities primarily as shade and resting cover. Utilization of ponderosa pine communities ranged from 10 to $27 \%$ (Fig. 1). Despite the relatively low level of utilization, significant changes did occur for some community parameters. Significant differences occurred between treatments within years with lower species richness in the exclosed treatment in 1989 (Table 1). Species richness in the exclosures of ponderosa pine communities was lowest of the tree dominated communities ranging from 31 to 37 species. Total species diversity was significantly higher in the grazed treatment in 1980 and 1989, possibly reflecting the effects of livestock grazing.

Species composition in ponderosa pine communities changed significantly over the study period. Elymus glaucus Buckl., a native graminoid increased significantly from 0 to $47.8 \%$ in the exclosures. Increases of Elymus glaucus in the grazed areas (6.7 to $28.9 \%$ ) were not significant. Frequencies of Ranunculus acris and Poa pratensis, both exotic species, were significantly higher in grazed than exclosed areas in 1989 (0.0 vs $19.6 \%$ and 61.6 vs $95.6 \%$, respectively). The relative abundance of $P$ oa pratensis in the exclosures declined significantly from $98.9 \%$ in 1979 to $61.1 \%$ in 1989. Montia perfoliata (Donn) How. showed significant increases in 1989 from 0.0 to $46.6 \%$ in exclosures and from 1.1 to $34.5 \%$ in grazed treatments.

Livestock utilization in black cottonwood communities ranged from 9 to $15 \%$ and 14 to $16 \%$ in thinleaf alder communities (Fig. 1). There were no significant changes in species richness (Table 1). Species richness in the grazed treatments of alder communities ranged from 45 to 56 , the highest of the tree dominated communities. The percent of exotic species was in thinleaf alder communities slightly higher on average in the grazed areas (30 vs 25\%). In black cottonwood communities eveness values in 1987 were significantly higher in the grazed areas. Species diversity was significantly higher in grazed areas when compared to exclosed areas of thinleaf alder communities in 1987 (Table 1).

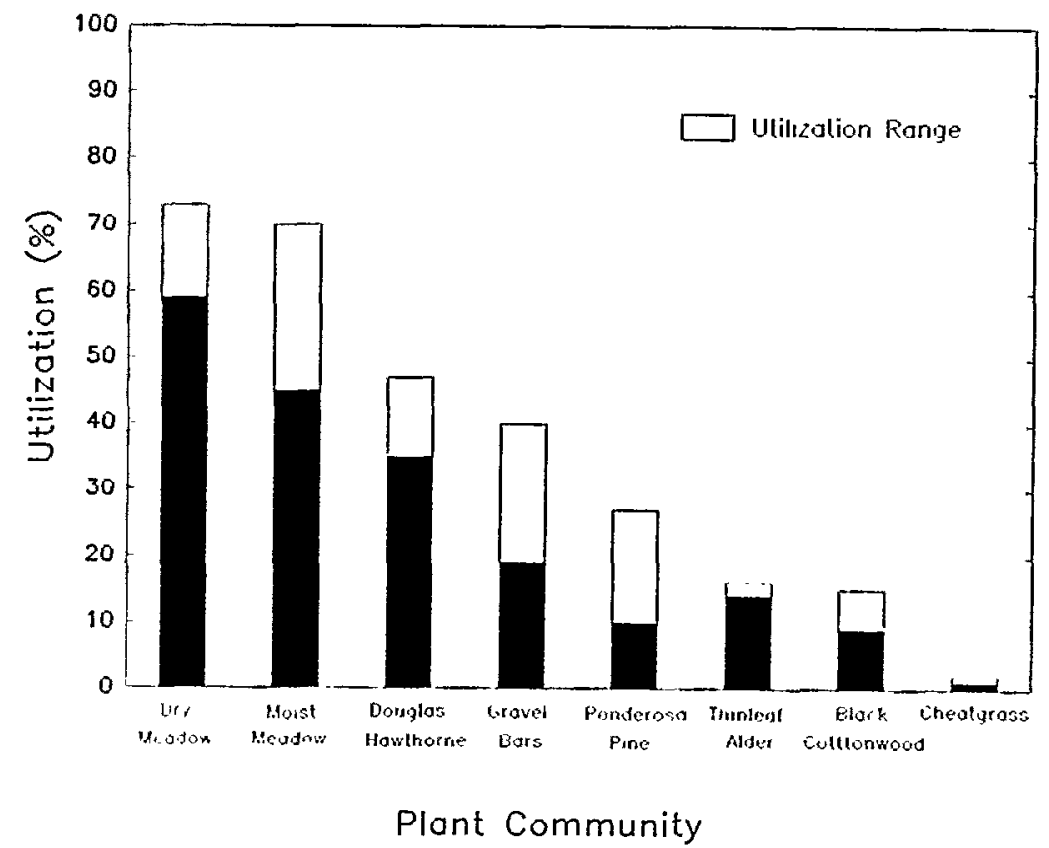

Fig. 1. Range of mean livestock utilization from 1978 to 1989 for 8 plant communities at the Catherine Creek study site. 
Table 1. Species richness (S), percent exotics, species diversity $\left(\mathrm{H}^{\prime}\right)$ species eveness $\left(\mathrm{J}^{\prime}\right)$, and percent utilization for all species in grazed $(\mathrm{G})$ and exclosed (E) plant communities along the Catherine Creek study site.

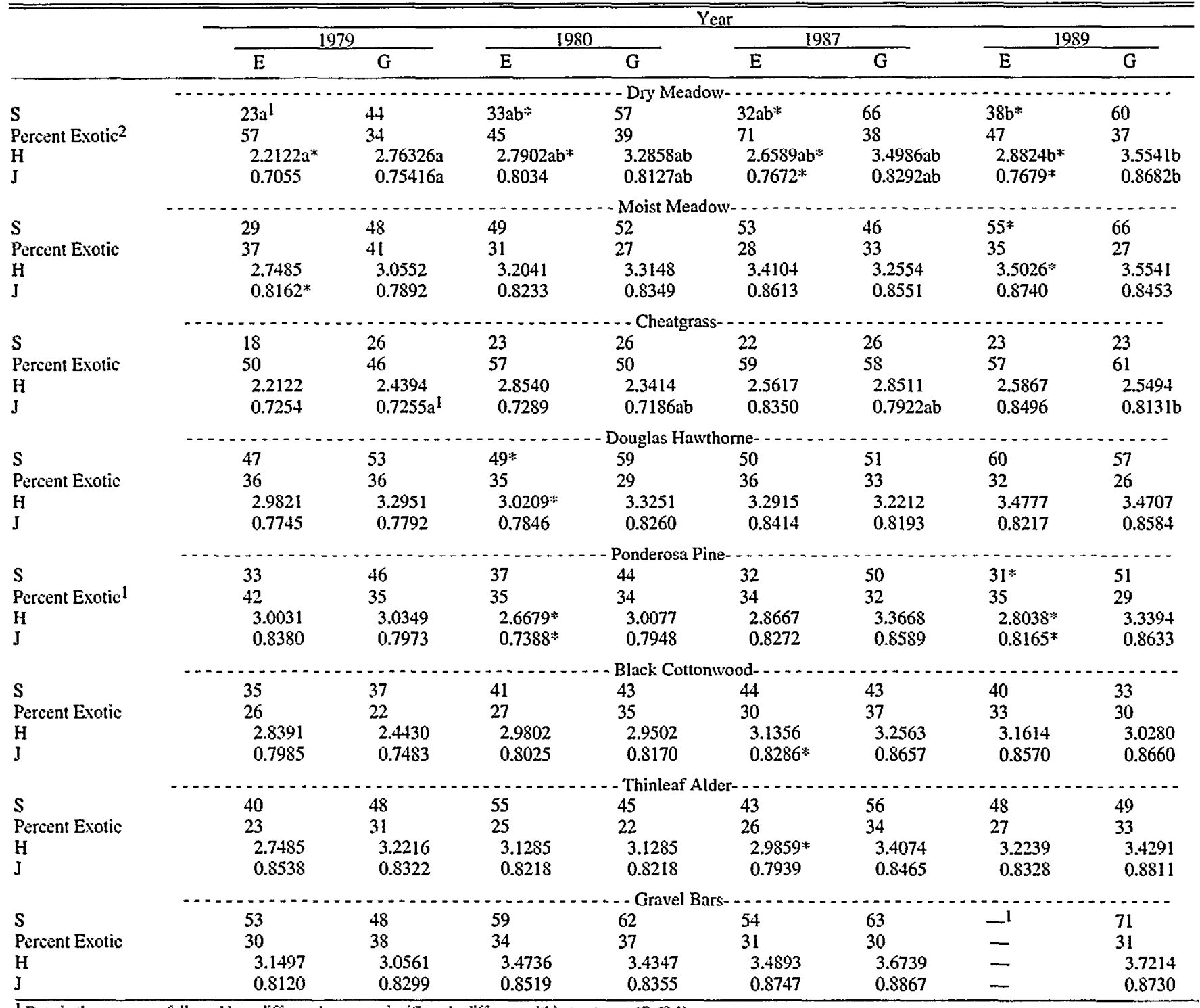

Data in the same row followed by a different letter are significantly different within treatment $(P \leq 0.1)$.

2 The percentage of total species encountered that are exotic or aliens.

* Significant differences between treatments within year $(P \leq 0.1)$.

\section{Gravel Bar Communities}

Lateral channel movement during the spring of 1989 removed all gravel bar community sampling sites located in exclosures. There were no significant differences for values of evenness or species diversity for any comparison within the gravel bar communities.

Livestock browsing had significant effects on the density and height of woody species. A total of 16 woody species were encountered in shrub density and height transects in gravel bar communities. Five of the most commonly occurring species were selected for detailed analysis. These were: Alnhus incana, Populus trichocarpa, Salix bebbiana var. perrustrata (Rydb.) Schneid., Salix exigua Nutt., and Salix rigida (Hook.) Cronq.. Mean heights of all species were significantly greater in the ungrazed than grazed areas in 1988 (Fig. 2). Comparisons between years indicated significant increases in height in exclosed gravel bar communities for all species. For example, mean height of Populus trichocarpa in exclosures increased from $15 \mathrm{~cm}$ in 1978 to $101 \mathrm{~cm}$ in 1988 . Conversely in grazed areas Populus trichocarpa height was 12 and $26 \mathrm{~cm}$ in 1978 and 1988 respectively.

After 10 years of no grazing the density of woody species was significantly greater (Fig 3). In 1988, stem densities of Alnus incana, Salix bebbiana, and Salix rigida were significantly higher where ungrazed. For example, mean stem density in exclosures for Alnus incana increased from $0.5 / \mathrm{m}^{2}$ in 1979 to $3.7 / \mathrm{m}^{2}$ in 1988. In grazed areas Alnus incana density was 0.4 to $0.3 / \mathrm{m}^{2}$ in 1978 and 1988 respectively (Fig. 3). Between years within the exclosed treatment, only Populus trichocarpa failed to show a significant increase in stem density. Significantly higher stem densities were measured for Salix exigua and Salix rigida within grazed stands between 1978 and 1988. 


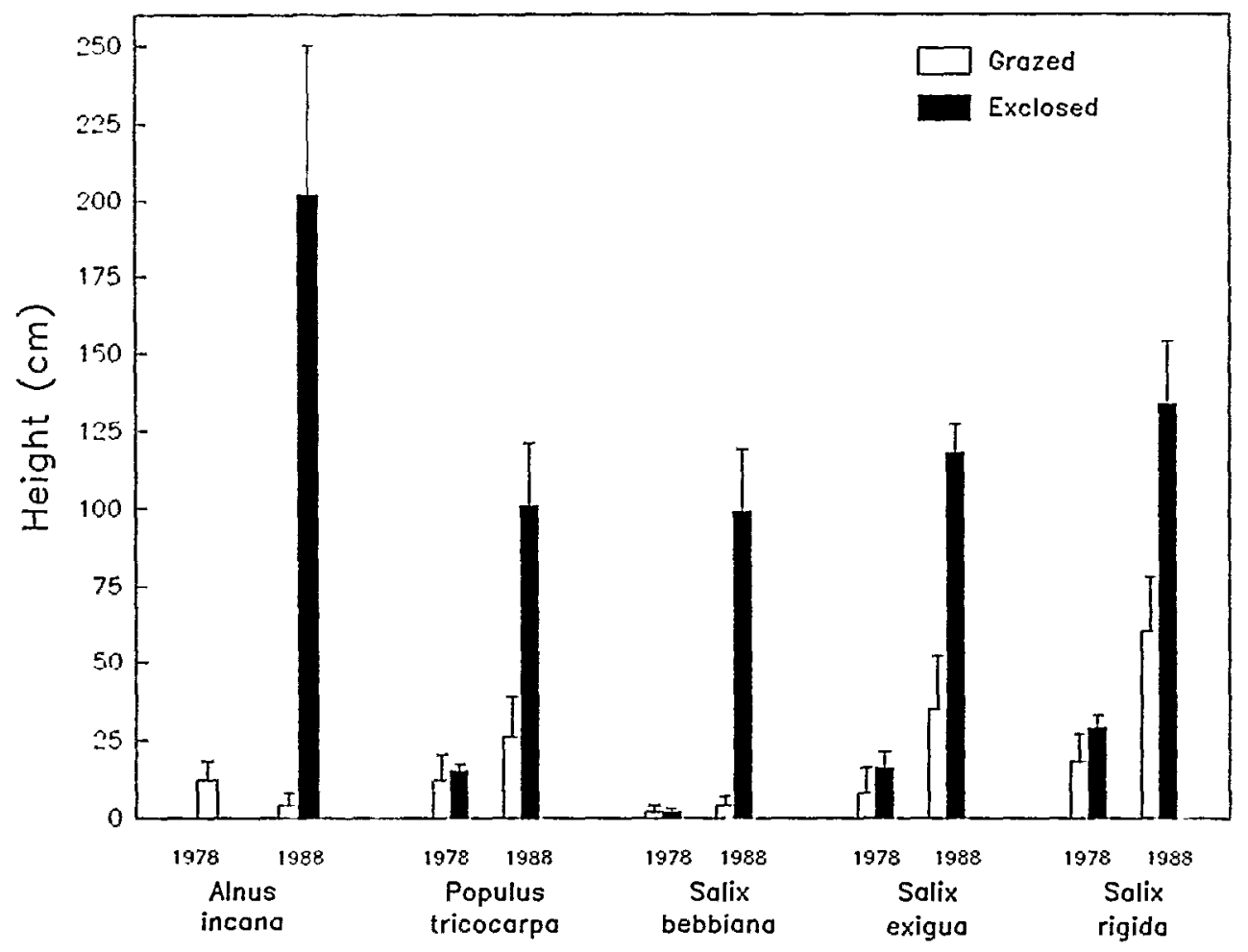

Fig. 2. Mean height (cm) for 5 commonly occurring woody species of gravel bar communities in 1978 and 1989 at the Catherine Creek study site.

\section{Discussion}

We found livestock disturbance and ecosystem response to be highly variable among communities. This is not surprising as livestock utilization in the grazed riparian zone ranged from 3 to $73 \%$ in the sampled communities. In addition, community structure ranged from relatively simple annual grasslands (cheatgrass) to structurally diverse black cottonwood- mixed conifer communities. The 8 plant communities sampled were comprised of over 250 species; more than 400 vascular plant species have been identified in the $3 \mathrm{~km}$ reach of Catherine Creek (Green 1991). Each species would be expected to respond to grazing in a differential manner as response will vary from one community to the next. Poa pratensis declined in abundance in grazed cottonwood communities while its abundance remained constant in dry meadow communities.

In the absence of livestock utilization, species richness, and species diversity decreased in dry and moist meadow communities. Reduction of species richness in exclosures also occurred in riparian meadow's in Idaho (Hayes 1978), New Zealand (Dobson 1973) and Nevada (Clary and Medin 1990). This appears to be due to declines in disturbance created by livestock that facilitated establishment of alien or weedy species. After 10 years of nongrazing in dry meadows the exotic, Poa pratensis has remained as the most dominant species while the abundance of Bromus mollis declined from 6 to less than $1 \%$, in addition, many exotic dicot species also declined. In ungrazed moist meadow communities a native sedge, Carex rostrata Stokes was the dominant species in 1989. Conversely, frequency of grazing-tolerant aliens significantly decreased in the exclosures (Green 1991). For example, the abundance of Ranunculus acris declined from $55 \%$ in 1979 to $12 \%$ in 1989 and Phleum pratense declined from 33 to $3 \%$ over the same time period. Taraxacum officinale, another introduced grazing-tolerant species also had declined in abundance from $52 \%$ in 1979 to $17 \%$ in 1978 .

The shift in species composition and dominance appears to follow a sinilar pattern to competition models presented by Grime (1979). These models indicated that competitive-ruderal species, (i.e., those adapted to resource abundant habitats with moderate disturbance such as the grazing regime of this study) are displaced by competitive species with decreasing disturbance. For example, the alien annual Bromus mollis possesses ruderal characteristics such as vigorous production by seeds and establishment capabilities in open disturbed sites. In ungrazed dry meadow communities, Poa pratensis would be considered the competitive species replacing Bromus mollis because of its ability to produce large amounts of persistent litter and vegetative reproduction by tillers and rhizomes. In moist meadow communities, Phleum pratense with a strategy intermediate between stress tolerant and competitive ruderal, and Ranunculaus acris, a competitive-stress-tolerant strategist (Grime et al. 1988) were maintained by grazing. When ungrazed, these species were displaced by the more competitive Carex rostrata. Competitive characteristics of Carex rostrata include early and rapid growth, a tall, dense growth form, vegetative reproduction, and production of copious amounts of persistent litter.

The litter layer in ungrazed dry and moist meadow communities was approximately twice that of their grazed counterparts in 


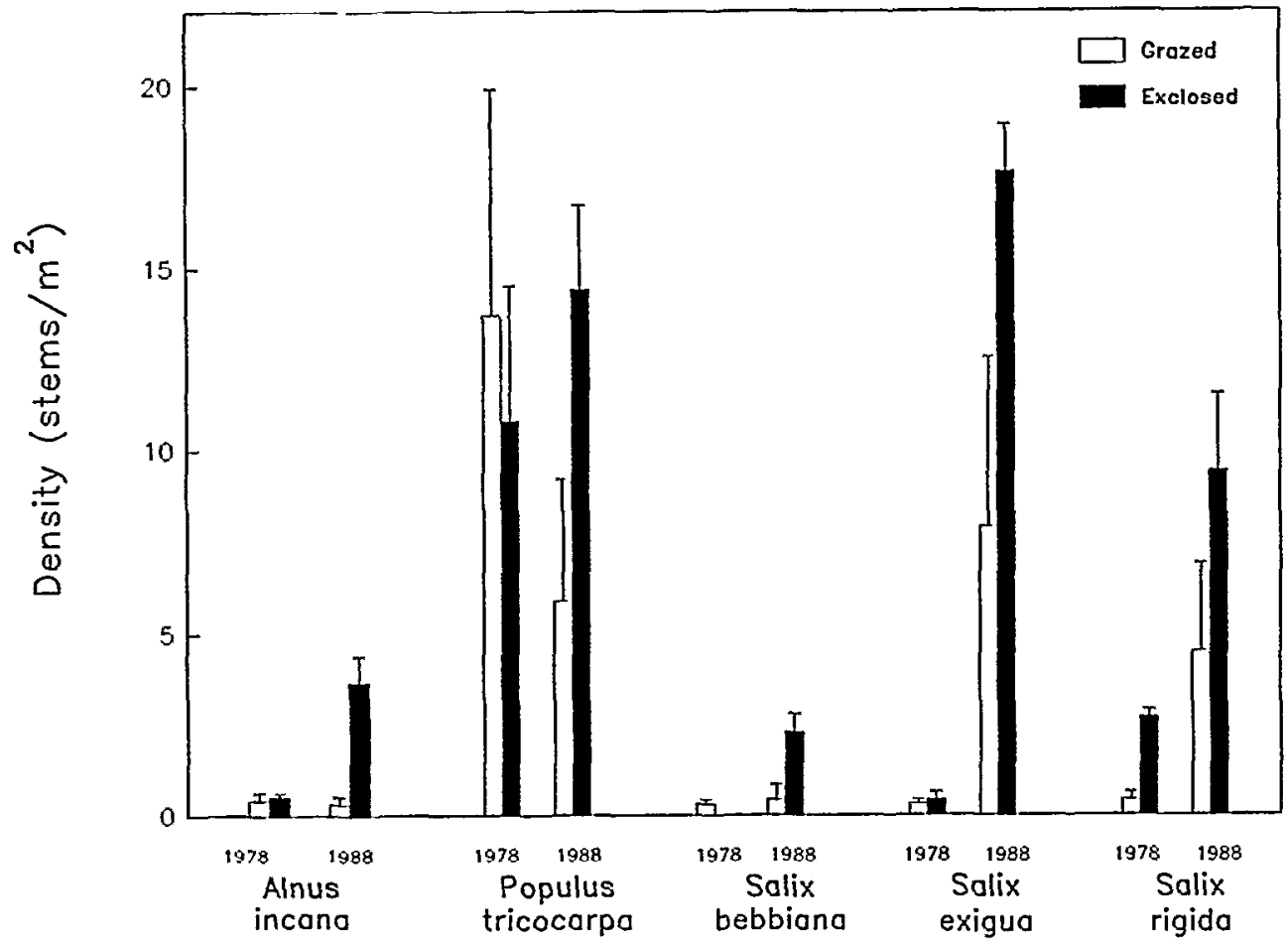

Fig. 3. Mean density (stems $/ \mathrm{m}^{2}$ ) for 5 commonly occurring woody species of gravel bar communities in 1978 and 1989 at the Catherine Creek study site.

1987 (Green 1991). This may have resulted in increased amounts of nutrients immobilized in the litter pool as well as changes in microclimate (e.g. soil temperature) and therefore a more competitive environment. Litter accumulation may also change soil temperature and moisture regimes, and decrease light availability for seedlings and species with a prostrate growth strategy.

The influences of herbivory on species composition differed in communities with tree and shrub overstories in comparison to meadow communities. This may be due to differing competitive relationships between species, conditions for regrowth, and patterns of herbivory which differed between communities (Louda et al. 1990). Poa pratensis, a commonly occurring species in every plant community sampled, (except cheatgrass communities) varied in its response to herbivory depending upon plant communities. The abundance of Poa pratensis did not change in moist or dry meadow communities in response to grazing, however, the abundance of Poa pratensis did decline significantly when grazed in Douglas hawthorne and black cottonwood communities, despite widely varying levels of utilization between these communities (Fig. 1). Likewise the frequency of Poa pratensis declined in ungrazed moist meadow, ponderosa pine, and black cottonwood communities, while in ungrazed dry meadows, and thinleaf alder communities no change occurred.

Morphology of Poa pratensis differed between forested communities and those with an open canopy. Compared to meadow communities, Poa pratensis in forested communities had larger, thinner leaves characteristic of shaded plants attempting to capture limited sunlight resources (Taylor and Pearcy 1976, Boardman 1977). Additionally, height growth, tillering, and dry matter accumulation by different ecotypes of Poa pratensis are strongly correlated to temperature and photoperiod at their place of origin (Aamlid 1992). The interactions of factors such as sunlight availability, mulch accumulation, temperature, grazing and other animal disturbances (e.g. trampling), points to the difficulty of generalizing the response of a key species to herbivory when it occurs in a variety of plant communities.

Density and height of establishing riparian tree species (i.e. Alnus incana, Populus trichocarpa, and Salix spp.) dramatically increased in exclosures (Figs. 2 and 3). Mean height of all woody species selected for analysis exceeded $1 \mathrm{~m}$ in the exclosures while in the grazed gravel bar communities, mean height was less than $0.5 \mathrm{~m}$ (Fig. 2). Shorter heights of woody species were the result of livestock browsing. Densities of woody species were greater after 10 years of no grazing for all species except for Salix rigida (Fig. 3). Utilization of woody species by livestock did not occur until the latter part of the grazing season when herbaceous forage appeared to become less available (personal observation). Other studies have also reported increases in height and density of riparian woody species following cessation of grazing (Gunderson 1968, Leege et al. 1981, Davis 1982, Schulz and Leininger (1990).

\section{Conclusions}

Late season grazing likely results in less disturbance to vegetation compared to season long or other livestock management systems commonly employed in adjacent riparian areas. Many of these other grazing systems result in greater utilization or selectivity of key riparian species.

In our study, disturbance from grazing and other livestock activities created conditions suitable for exotic and ruderal species. Species diversity was relatively stable in grazed stands of the plant communities studied. However structural diversity of woody plant communities was affected through declines in the density and growth of riparian obligate tree species. Heights of 
woody species were significantly less in grazed as compared to ungrazed stands and never was reproduction and establishment in grazed gravel bar communities as vigorous as ungrazed areas. We feel by suggesting blanket recommendations for livestock utilization to maintain riparian zones, many investigators and managers have ignored the inherent complexity of riparian ecosystems (e.g. Clary and Webster 1989, Bryant 1985). These recommendations call for a uniform level of utilization and or herbaceous stubble height after grazing to maintain riparian values however, each plant community responds differently to grazing. The restoration and maintenance of riparian ecosystem functions and values will depend not on general grazing prescriptions, but on developing grazing prescriptions for specific riparian areas.

\section{Literature Cited}

Aamlid, T.S. 1992. Effects of temperature and photoperiod on growth and development of tillers and rhizomes on Poa pratensis L. ecotypes. Annals. of Bot. 69:289-296.

Ahrens, W.H., D.J. Cox, and G. Budhwar. 1990. Use of aresine and square root transformations for subjectively determined percentage data. Agron. J. $38: 452-458$

Boardman, N.K. 1977. Comparative photosynthesis of sun and shade plants. Ann. Rev. of Plant Physiol. 28:131-355.

Brown, G.W. 1983. Forestry and water quality. Oregon State Univ. Book Stores Inc., Corvallis, Ore.

Bryant, L.M. 1985. Livestock management in the riparian ecosystem. p. 285$289 \mathrm{ln}$ : R.R. Johnson, C.D. Ziebell, D.R. Patton, P.F. Ffolloitt, and R.H. Hamre, coordinators. Riparian Ecosystmes and their management: Reconciling conflicting uses. First North American Riparian Conference. USDA Forest Serv. Gen. Tech. Rep. RM-120.

Clary, W.P., and B.F. Webster. 1989. Managing grazing of riparian areas in the intermountain region. USDA. Forest. Serv. Gen. Tech. Rep. INT-263.

Clary, W.P., and D.E. Medin. 1990. Differences in vegetation biomass and structure due to cattle grazing in a northern Nevada riparian ecosystem. USDA Forest Serv, Gen. Tech. Rep. INT-427.

Cooper, J.R., J.W. Gilliam, R.B. Daniels, and W.P. Robarge. 1987. Riparian areas as filters for agriculture sediment. Soil Sci. Soc. of Amer. J. $57: 416-420$

Davis, J.W. 1982. Livestock vs riparian habitat management-there are solutions. p. 175-184 In: Wildlife-Livestock Relationships Symposium. Univ. of Idaho. Forest, Wildlife, and Range Exp. Sta. MIoscow. Ida.

Dobson, A.T. 1973. Changes in the structure of a riparian community as the result of grazing. Proc. of the New Zealand Ecol. Soc. 20:58-64.

Elmore, W. 1992. Riparian responses to grazing practices. p. 442-457. In: R.J. Naiman. (ed.), Watershed Mlanagement: balancing sustainability and environmental change. Springer-Verlag. N.Y.

Green, D.M. 1991. Soil conditions along a hydrologic gradient and successional dynamies in a grazed and ungrazed montane riparian ecosystem. PhD. Diss., Oregon State Univ., Corvallis, Ore.

Green, D.M., and J.B. Kauffman. 1989. Nutrient cycling at the land-water interface: the importance of the riparian zone. p. 61-68 lin: Practical approaches to riparian resource management: an educational workshop, Billings, Mont.

Grime, J.P. 1979. Plant strategies and vegetation processes. John Wiley \& Sons Inc., N.Y.

Grime J.P., J.G. Hodgson, and R. Hunt. 1988. Comparative plant ecology: A functional approach to common British species. Allen and Unwin, Boston.

Gunderson, D.R. 1968. Floadplain use related to stream morphology and fish populations. J. of Wild. Manage. 32:507-514.

Harmon, M.E., and twelve coauthors. 1986. Ecology of coarse woody debris in temperate ecosystems. Advan. in Ecol. Res. 15:133-302.

Hayes, F.A. 1978. Streambank and meadow condition in relation to livestock grazing in mountain meadows of central Idaho. M.S. Thesis, Univ. of Idaho, Mloscow, Ida.

Heede, B.H. 1990. Vegetation strips control erosion in watersheds. USDA Forest Serv. Res. Note RM1-499.
Hussey, M.R., Q.D. Skinner, J.C. Adams, and A.J. Harvey. 1985. Denitrification and bacterial numbers in riparian soils of a Wyoming watershed. J. of Range Manage. 38:492-496.

Kauffman, J.B. 1982. Synecological effects of cattle grazing riparian ecosystems. M.S. thesis. Oregon State Univ. Corvallis, Ore.

Kauffman, J.B., W.C. Krueger, and M. vavra. 1983. Effects of late season cattle grazing on riparian plant communities. J. of Range Manage. 36:685691.

Kauffman, J.B., K.G. Busse, D. Green, and W.C. Krueger. 1988. Impacts of herbivory on riparian meadows: 10 years of change in grazed and ungrazed communities. Abstr. of Paper. 4lst Ann. Meet., Soc. for Range Manage., Corpus Christi. Tex.

Leege, T.A., D.J. Herman, and B. Zamora. 1981. Effects of cattle grazing on mountain meadows in Idaho. J. of Range Manage. 34:324-328.

Louda M.S., K.H. Keeler, and R.D. Holt. 1990. Herbivore influences on plant performance on competitive interactions. p. 413-444 In: J.B. Grace and D. Tilman. (eds), Perspectives on plant competition. Academic Press Inc., San Diego. Calif.

Ludwig, J.A., and J.F. Reynolds. 1988. Statistical ecology: a primer on methods and computing. John Wiley \& Sons Inc.. N.Y.

Meehan, W.R., F.J. Swanson, and J.R. Sedell. 1977. Intluences of riparian vegetation on aquatic ecosystems with particular reference to salmonid fishes and their food supply. p. 137-143 In: Importance, preservation and management of riparian habitat. USDA Forest Serv. Gen. Tech. Rep. RM-4

Peet, R.K. 1974. The measurement of species diversity. Ann. Rev. of Ecol. and Syst. 5:285-307.

Peterjohn, W.T., and D.L. Correll. 1984. Nutrient dynamics in an agricultural watershed: observations on the role of a riparian forest. Ecology 65:1466-1475.

Pielou, E.C. 1975. Ecological diversity. John Wiley \& Sons Inc., New York, N.Y.

Platts, W.S. 1979. Livestock grazing and riparian/stream ecosystems. p. 39$45 \mathrm{ln}$ : O.B. Cope, (ed), Forum on grazing and riparian/stream ecosystems. Trout Unlimited Inc. Denver, Colo.

Platts, W.S. 1989. Compatibility of livestock grazing strategies with fisheries. p. 103-110 In: R.E. Gresswell, B.A. Barton, and J.L. Kershner, (eds), Practical approaches to riparian resource management: an educational workshop, Billings, Mont.

Robinson G.E., and R. L. Beschta. 1990. Coarse woody debris and channel morphology interactions for undisturhed streams in southeast Alaska, U.S.A. Earth Processes and Landforms. 15:149-156.

Schulz, T.T., and W.C. Leininger. 1990. Differences in riparian vegetation structure between grazed areas and exclosures. J. of Range Manage. 43:295-299.

Shannon, C.E., and W.Weaver. 1949. The mathematical theory of communication. Univ. of Illinois Press. Urbana, Ill.

Skovlin, J.M. 1984. Impacts of grazing on wetlands and riparian habitat: a review of our knowledge. p. 1001-1103 In: Developing strategies for rangeland management. Westvicw Press, Boulder. Colo.

Steel, R.G.D., and J.H. Torrie. 1980. Principles and procedures of statistics. McGraw-Hill Book Co., New York, N.Y.

Swanson, F.J., S.V. Gregory, J.R. Sedell, and A.G. Campbell. 1982. Landwater interactions: The riparian zone. p. 267-291. $\mathrm{lm}$ : Analysis of the coniferous forest ecosystems in the western United States. US/IBP Synthesis Series 14. Hutchinson Ross Publishing Co., Stroudsburg, Penn.

Taylor, O, R., Jr. and R.W. Pearcy. 1976. Seasonal patterns of $\mathrm{CO}_{2}$ exchange characteristics of understory plants from a deciduous forest. Can. J. Bot. 54:1094-1103.

Triska, F.J., J.R. Sedell, and S.V. Gregory. 1982. Coniferous forest streams. p. 292-332. In: Analysis of the coniferous forest ecosystems in the western United States. US/IBP Synthesis Series 14. Hutchinson Ross Publishing Co., Stroudsburg. Penn.

United States Geological Survey. 1987. Water resources data for Oregon: Surface water records for eastern Oregon, vol. 1.

Van Poolen, H.W., and J.R. Lacy. 1979. Herbage response to grazing systems and stocking intensities. J. of Range Manage. 32:250-253.

Zar, J.H. 1984. Biostatistical analysis. Prentice-Hall, Inc., Englewood Clífis, N.J. 